\title{
ANALIZA ANTROPOLOGICZNA MATERIALU KOSTNEGO Z WYKOPÓW NR 69 I 70 ZE STANOWISKA POZNAŃ-OSTRÓW TUMSKI 9/10
}

\author{
ANTHROPOLOGICAL EXAMINATION OF OSTEOLOGICAL \\ MATERIAL FROM TRENCHES NUMBER 69 AND 70 \\ AT POZNAŃ-OSTRÓW TUMSKI 9/10
}

\author{
Anna Kubicka \\ Instytut Antropologii, Uniwersytet im. Adama Mickiewicza w Poznaniu \\ ul. Umultowska 89, 61-614 Poznań, Poland
}

\begin{abstract}
The purpose of this study was to estimate the sex, age structure and minimum number of individuals (MNI) of human skeletal remains found in trenches number 69 and 70 located in St Mary's Church in Ostrów Tumski. A new methodology had to be created as a consequence of bone fragmentation and the absence of preserved anatomical system. The lower limit of the group was obtained by adding the number of particular bones found in their entirety to the number of ends of the same bone. Sex and age were determined on the basis of skulls.

The best quantitative indicators for adult vs immature status were femurs. Somewhat less useful was tibias. Based on the new methodology, the MNI for excavation no. 69 was 17 adult, 6 immature; for in excavation no. 70, 229 adult, 17 immature.

Femurs and tibias were distinguished by the best state of preservation due to their robustness and characteristic anatomical structure, which facilitated the identification of even small elements. The disadvantage of this research was that only the lower limit of the group could be determined.
\end{abstract}

\section{WSTĘP}

Analiza grobów masowych oraz ossuariów wymaga współpracy specjalistów z dziedziny antropologii i archeologii. Wyniki tych badań mają ogromne znaczenie poznawcze, gdyż służą udoskonaleniu metodyki, jak i praktyczne - pomocne w interpretacji archeologicznej. Opracowania dotyczące sposobu studiowania grobów masowych są dość liczne w światowej literaturze ${ }^{1}$. W przypadku gdy liczba osobników w danym pochówku jest trudna do ustalenia, a układ anatomiczny słabo

${ }^{1}$ Thomas 2003; Hunter, Cox 2005; Bradley 2008; Pickering, Bachman 2009. 
zachowany, należy brać pod uwagę zbiór wybranych cech. Jedną z nich jest ocena kolorystyki poszczególnych kości, gdyż bardzo często elementy pochodzące od jednego osobnika mają podobne barwy. Inną stosowaną techniką jest porównanie wielkości kości z obu stron. Przydatna jest również analiza podobieństwa kości połączonych ze sobą w stawie (np. kości udowej z kością piszczelową).

Pomocną czynnością jest także porównanie stopnia starcia zębów i zgryzu żuchwy ze stanem zębów szczęki. Ostatnią fazą procedury powinna być ocena płci na podstawie morfologii czaszki, kości miednicznej i innych kości - w celu zwiększenia prawdopodobieństwa właściwej oceny. Obecnie wykorzystywane jest także skanowanie 3D pochówków i wykopów. Trójwymiarowe obrazowanie ułatwia szczegółową analizę rozmieszczenia ciał i ustalenie przynależności elementów szkieletu postkranialnego do właściwych osobników².

Takie podejście metodologiczne jest możliwe do zastosowania m.in. w przypadku badań ofiar katastrof (trzęsienia ziemi, powodzie) lub XX-wiecznych mogił wojennych. Ze względu na całkowicie odmienny charakter materiału z Ostrowa Tumskiego (zbyt duża fragmentacja i wymieszanie kości) wykorzystanie przyjętej procedury okazało się niemożliwe. Stąd też należało stworzyć odmienną metodykę, umożliwiającą określenie struktury wieku, płci i minimalnej liczby osobników pochowanych na obu stanowiskach.

\section{MATERIAL}

Niniejsze opracowanie dotyczy materiału pochodzącego z kościoła Najświętszej Marii Panny na Ostrowie Tumskim. Teren ten jest obecnie jedyną wyspą na Warcie, w granicach administracyjnych Poznania, między głównym korytem Warty (koryto szersze) a kanałem ulgi, ujścia Cybiny (koryto węższe). Pierwsze wykopaliska przy kościele Najświętszej Marii Panny rozpoczęły się w 1938 r. Od 1999 prace wykonywane są pod kierownictwem Pani prof. Hanny Kóčki-Krenz z Instytutu Prahistorii UAM w Poznaniu.

W wykopach nr 69/2011 i 70/2011 (ryc. 1) natknięto się na dużą ilość ludzkiego materiału kostnego bez zachowanego układu anatomicznego. Wykop nr 69 to nowożytna krypta ceglana ze schodami, znajdująca się przy wschodnim fundamentowaniu kościoła o wymiarach 2,8 $(3,0) \times 1,6 \mathrm{~m}$. We wnętrzu odkryto dwie koncentracje wymieszanego kośćca: po stronie południowej i północnej. Materiał ten przykryty był warstwą gruzu ceglanego, na który składała się m.in. zaprawa wapienna, kształtki oraz cegły. Najniżej położonymi pochówkami były groby duchownych, na co wskazuje obecność resztek stuły i ornatów. Wykop drugi (o wymiarach 3,6×1,5 m) to ossuarium, które znajdowało się w centralnej części kościoła, w zdecydowanej większości wypełnione szczątkami kostnymi dwukrotnie zsypywanymi (ryc. 2).

\footnotetext{
${ }^{2}$ Brothwell 1981.
} 


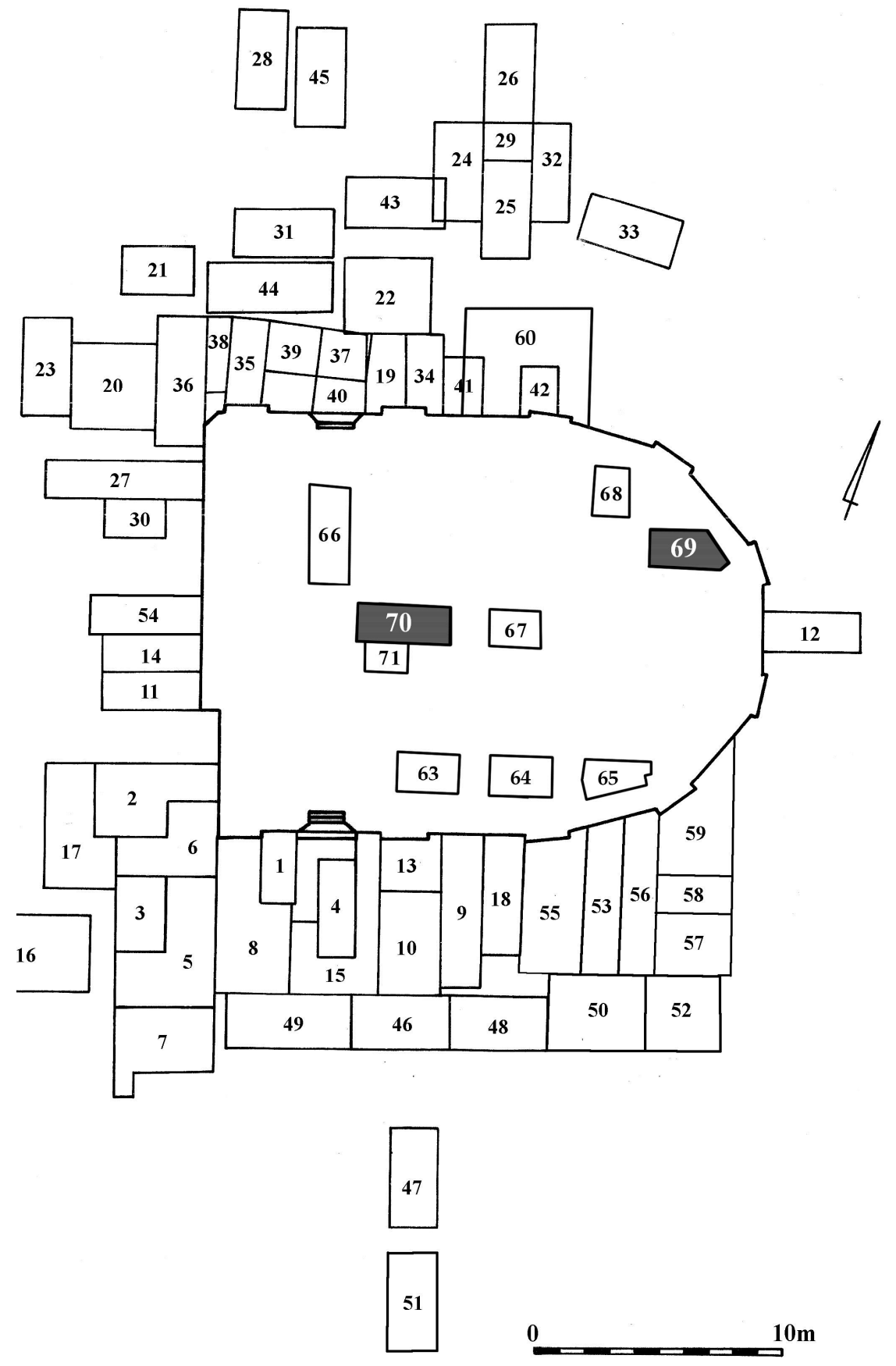

Ryc. 1. Plan zbiorczy kościoła Najświętszej Marii Panny z lokalizacją wykopów archeologicznych nr 69 i nr 70 (autor: Olga Antowska-Gorączniak)

Fig. 1. Layout of the St. Mary's Church with trenches No. 69 and 70 (by Olga Antowska-Gorączniak) 


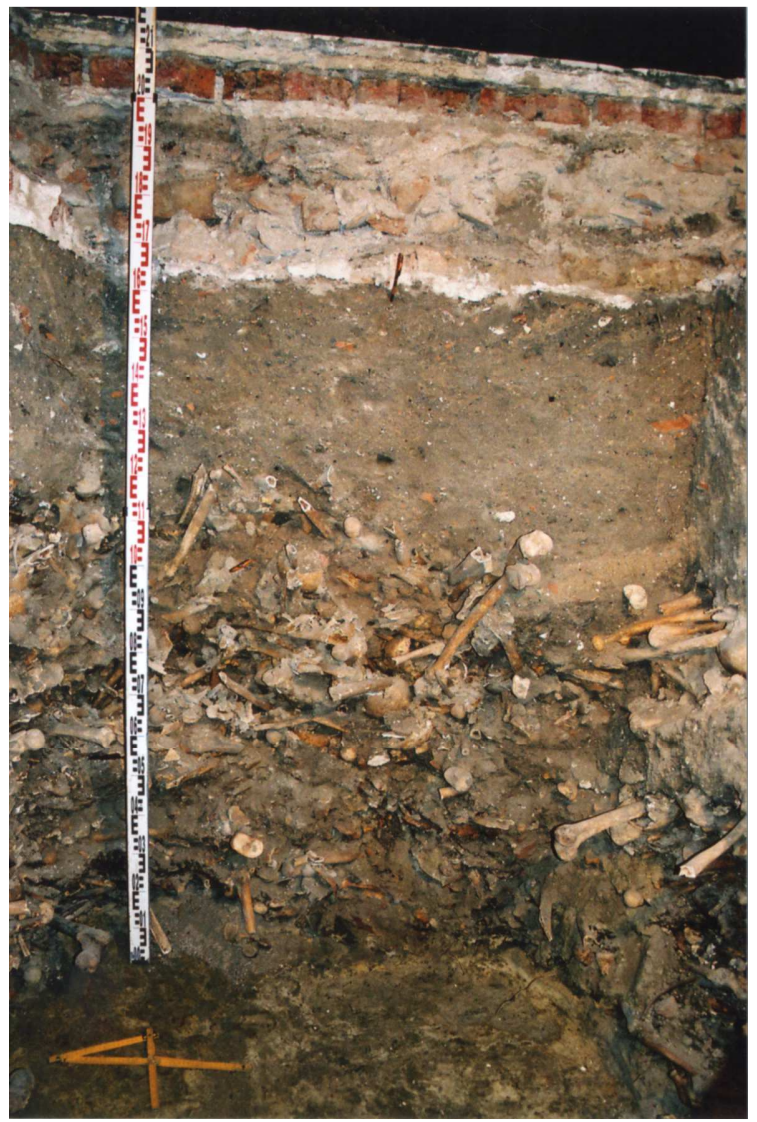

Ryc. 2. Profil wschodni wykopu archeologicznego $\mathrm{nr} 70 \mathrm{z}$ widocznym materiałem kostnym (autor: Andrzej Sikorski)

Fig. 2. Eastern cross-section of trench No. 70 with visible bone remains (by Andrzej Sikorski)

Na podstawie drobnych wyposażeń grobowych (elementy ubiorów i butów, szpilek, taśm i koronek metalowych trumien, nitów) ustalono, że badany materiał pochodził z okresu nowożytnego, lecz nie można wykluczyć przeniesienia szczątków ludzkich z okresu średniowiecza.

\section{METODY}

Ze względu na dość specyficzny materiał, charakteryzujący się dużym stopniem wymieszania szkieletów, zastosowanie tradycyjnego antropologicznego podejścia badawczego było praktycznie niemożliwe. Dlatego też zaistniała potrzeba opracowania nowej techniki. Zadanie badawcze zostało podzielone na dwa etapy. 
W pierwszej kolejności skupiono się na szkielecie postkranialnym. Analiza miała na celu ustalenie przybliżonej liczby osób znajdujących się w danym wykopie. Kolejność działań była następująca:

1) rozpoznanie kości długich,

2) określenie stron ciała,

3) zliczenie poniższych elementów (z wydzieleniem rodzaju kości i ich strony):

a) końców bliższych kości,

b) końców dalszych kości,

c) trzonu kości,

d) całych kości,

4) stworzenie bazy danych.

Dzięki uzyskanym danym możliwe było oszacowanie minimalnej liczebności osobników - MNI (minimal number of individuals), czyli dolnej granicy wielkości grupy, poprzez zsumowanie liczby poszczególnych kości całych z najliczniej reprezentowanym końcem. W końcowych obliczeniach nie wzięto pod uwagę trzonów kości, ze względu na ich zbyt dużą fragmentację. Próbki wykazujące charakter patologiczny również zostały wliczone i dodatkowo sfotografowane ze skalą. Otrzymanie górnej granicy było możliwe poprzez dodanie do siebie wszystkich zliczonych elementów (cała kość + trzon + koniec proksymalny + koniec dystalny). Uzyskana dzięki temu maksymalna wartość okazała się na tyle duża, że prawdopodobieństwo, aby dana grupa faktycznie liczyła tyle osób, jest bardzo znikome.

$\mathrm{Z}$ powodu nadmiernej ilości zachowanych fragmentów kostnych liczenie objęło wyłącznie takie kości długie, jak: kość ramienna, kość promieniowa, kość łokciowa, kość udowa oraz kość piszczelowa. Skupiono się także na pozostałych elementach szkieletu postkranialnego, m.in. na kości piętowej, kości skokowej oraz obojczyku, który ze względu na swoją krępą budowę zachował się niemal zawsze w całości. W przypadku łopatki odnotowywano obecność wyłącznie części stawowej, a w przypadku mostka - jego rękojeści.

Drugi etap prac przeprowadzono na grupie, do której zaklasyfikowane zostały szczątki osób starszych niż 20 lat. Celem badania była ocena wieku i płci. Do analizy wykorzystano czaszki, które przyporządkowano do jednego z trzech stanów zachowania: Calvarium ( $\mathrm{Cv}$ - kompletna czaszka bez żuchwy), Calvaria $(\mathrm{Cl}$ - czaszka bez części twarzowej i żuchwy), Calva s. Calotta (Ca - sklepienie czaszki). Brak stopnia Cranium (kompletna czaszka z żuchwą) spowodowany był trudnością w dopasowaniu żuchwy do konkretnego osobnika.

Do oceny płci wykorzystano metodę zaproponowaną przez Acsádiego i Nemeskeriego ${ }^{3}$. Natomiast $\mathrm{w}$ celu określenia wieku w chwili śmierci osobników dorosłych zastosowano ocenę stopnia obliteracji szwów czaszkowych ${ }^{4}$. Z powodu słabo zachowanego materiału kostnego pochodzącego z Ostrowa Tumskiego zastosowano

\footnotetext{
${ }^{3}$ Ascádi, Nemeskeri 1970.

${ }^{4}$ Martin, za: Piontek 1996.
} 
ogólny podział wiekowy, spotykany w polskojęzycznych publikacjach. Wyróżniono następujące kategorie: adultus (20-35 lat), maturus (35-55 lat) oraz senilis (> 55 lat). W przypadku kości dziecięcych zastosowano wyłącznie etap pierwszy badań. Określenie struktury wiekowej było niemożliwe ze względu na małą ilość i niekompletny materiał. Z kolei u osobników poniżej 20. roku życia nie określa się płci z powodu niedostatecznego wykształcenia cech płciowych.

\section{WYNIKI}

Ze względu na zastosowanie nieco innej metodologii dla osobników dorosłych i dziecięcych oraz odmienny charakter dwóch wykopów, wyniki badań przedstawiono w osobnych podrozdziałach.

\section{Analiza szczątków osobników dorosłych z wykopu nr 69}

W tabeli 1 pogrubioną czcionką zostały zaznaczone wartości dla kości całych i najliczniejszego końca (proksymalnego lub dystalnego). Sumę poszczególnych kości otrzymano w wyniku dodania tych dwóch różnych wielkości. Z kolei na ryci-

Tabela 1. Liczebność elementów dla poszczególnych kości osobników dorosłych z wykopu nr 69 Table 1. Number of adult bones elements from trench No. 69

\begin{tabular}{|c|c|c|c|c|c|c|c|c|}
\hline \multirow{2}{*}{$\begin{array}{c}\text { Szkielet } \\
\text { postkranialny }\end{array}$} & \multicolumn{3}{|c|}{ Lewa strona ciała } & \multirow[b]{2}{*}{ Suma } & \multicolumn{3}{|c|}{ Prawa strona ciała } & \multirow[b]{2}{*}{ Suma } \\
\hline & $\begin{array}{c}\text { koniec } \\
\text { proksym. }\end{array}$ & $\begin{array}{l}\text { koniec } \\
\text { dystalny }\end{array}$ & $\begin{array}{l}\text { cała } \\
\text { kość }\end{array}$ & & $\begin{array}{c}\text { koniec } \\
\text { proksym. }\end{array}$ & $\begin{array}{l}\text { koniec } \\
\text { dystalny }\end{array}$ & $\begin{array}{l}\text { cała } \\
\text { kość }\end{array}$ & \\
\hline $\begin{array}{l}\text { Humerus } \\
\text { (k. ramienna) }\end{array}$ & 2 & 5 & 4 & 9 & 2 & 8 & 9 & 17 \\
\hline $\begin{array}{l}\text { Radius } \\
\text { (k. promieniowa) }\end{array}$ & 1 & 1 & 7 & 8 & 4 & 2 & 7 & 11 \\
\hline Ulna (k. łokciowa) & 8 & 2 & 9 & 17 & 11 & 2 & 4 & 15 \\
\hline Femur (k. udowa) & 5 & 8 & 8 & 16 & 9 & 10 & 6 & 16 \\
\hline $\begin{array}{l}\text { Tibia } \\
\text { (k. piszczelowa) }\end{array}$ & 4 & 1 & 10 & 14 & 5 & 4 & 9 & 14 \\
\hline $\begin{array}{l}\text { Talus } \\
\text { (k. skokowa) }\end{array}$ & & & 4 & 4 & & & 9 & 9 \\
\hline $\begin{array}{l}\text { Calcaneus } \\
\text { (k. piętowa) }\end{array}$ & & & 5 & 5 & & & 4 & 4 \\
\hline $\begin{array}{l}\text { Clavicle } \\
\text { (obojczyk) }\end{array}$ & & & 9 & 9 & & & 7 & 7 \\
\hline Scapula (łopatka) & & & 8 & 8 & & & 9 & 9 \\
\hline $\begin{array}{l}\text { Sternum } \\
\text { (mostek) }\end{array}$ & & & & & & & & \\
\hline
\end{tabular}




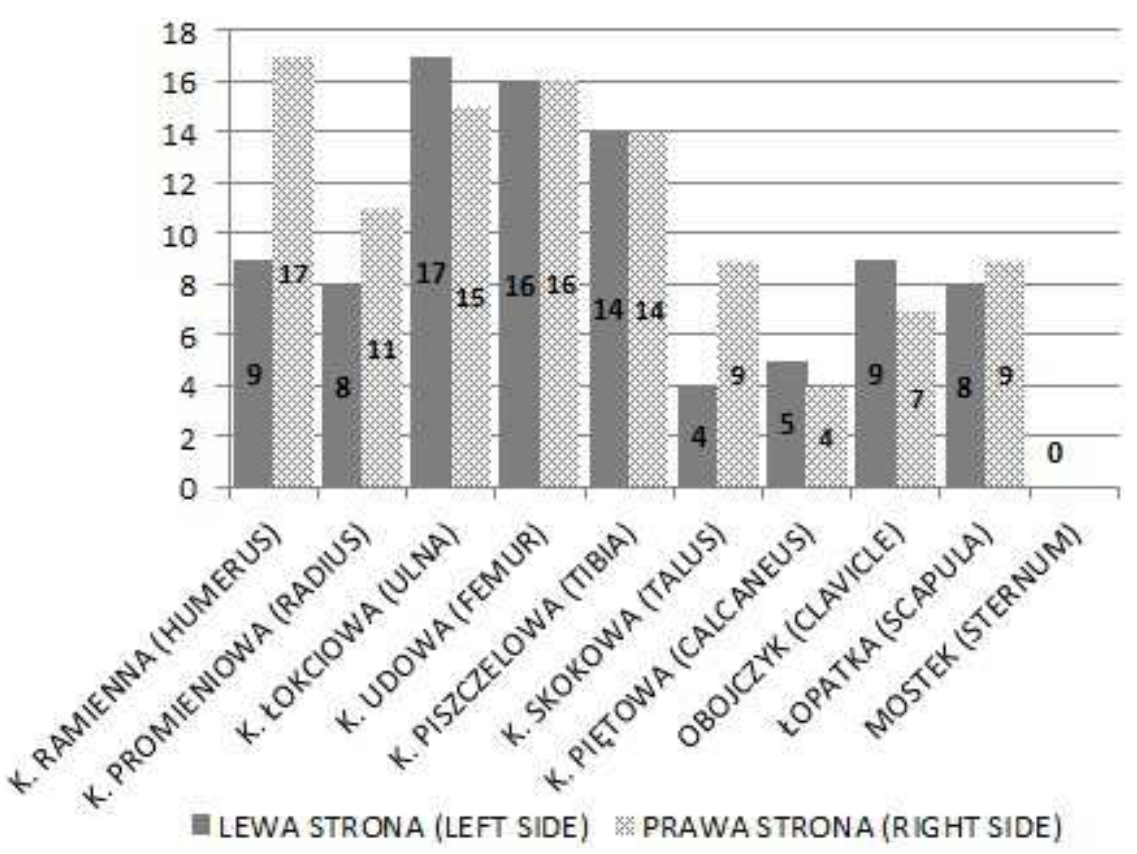

Ryc. 3. Ostateczne wartości dla szkieletu postkranialnego osobników dorosłych z wykopu nr 69 Fig. 3. Final values of adult postcranial bones from trench No. 69

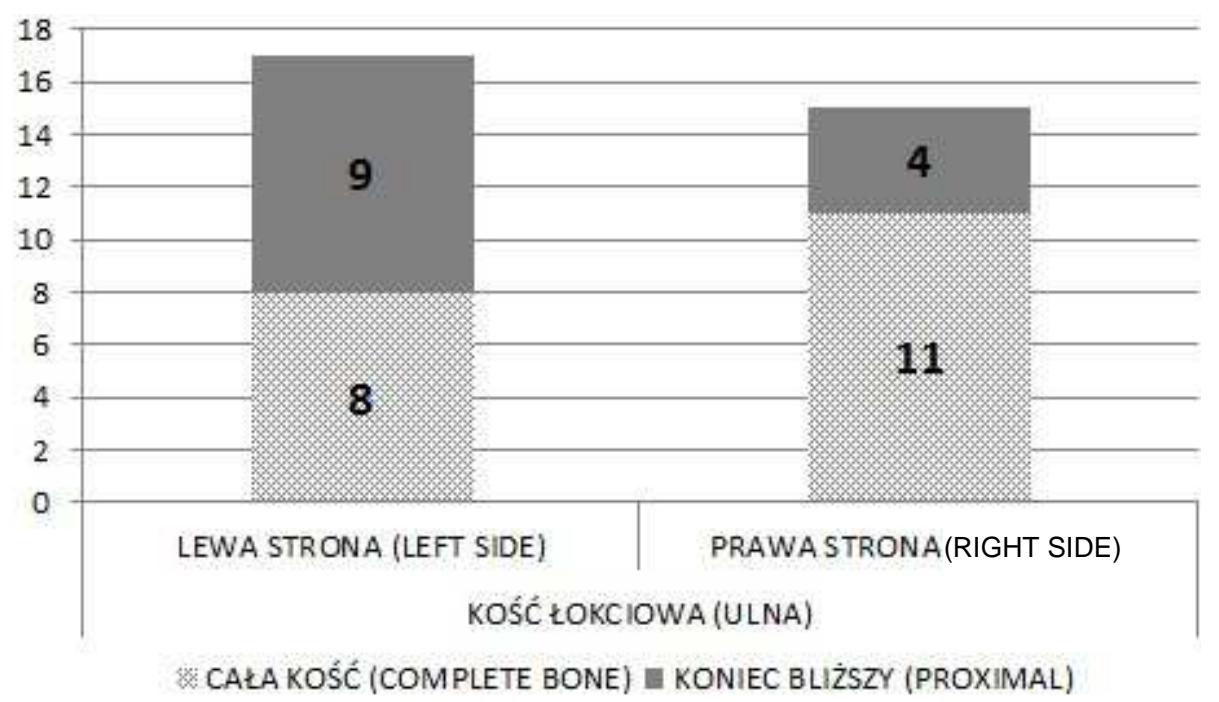

Ryc. 4. Ostateczna liczebność kości łokciowej po zsumowaniu kości całych i najliczniejszego końca w poszczególnej stronie ciała

Fig. 4. Final number of ulna in total number of complete bones and the most numerous end in particular body side 
nie 3 przedstawiono ostateczne wartości poszczególnych kości szkieletu postkranialnego po zsumowaniu elementów całych i jednego z końców. Najbardziej liczebne są: kość ramienna (tylko prawa strona), kość łokciowa oraz kość udowa. W materiale wykopaliskowym nie odnotowano mostka. W przypadku kości ramiennej, promieniowej oraz skokowej zaobserwować można, iż jedna ze stron występowała częściej.

Na podstawie liczby zachowanych prawych kości łokciowych (ryc. 4) można wywnioskować, iż w krypcie zostało pochowanych nie mniej niż 17 osób, a najbardziej licznym końcem jest część bliższa.

Z wykopu nr 69 ocenie płci poddano 14 czaszek, z czego tylko w jednym przypadku stan zachowania był na tyle zły, iż wykonanie badania było niemożliwe. Siedem czaszek zakwalifikowano jako kobiece, a sześć jako męskie.

Na podstawie ryciny 5 można stwierdzić, iż $54 \%$ badanych czaszek posiadało cechy żeńskie, natomiast $46 \%$ cechy męskie. Otrzymane rezultaty mogą przedstawiać (lecz z dużą ostrożnością) procentowy rozkład wszystkich pochowanych dorosłych osobników, czyli grupy liczącej co najmniej 17 osób, w wykopie nr 69.

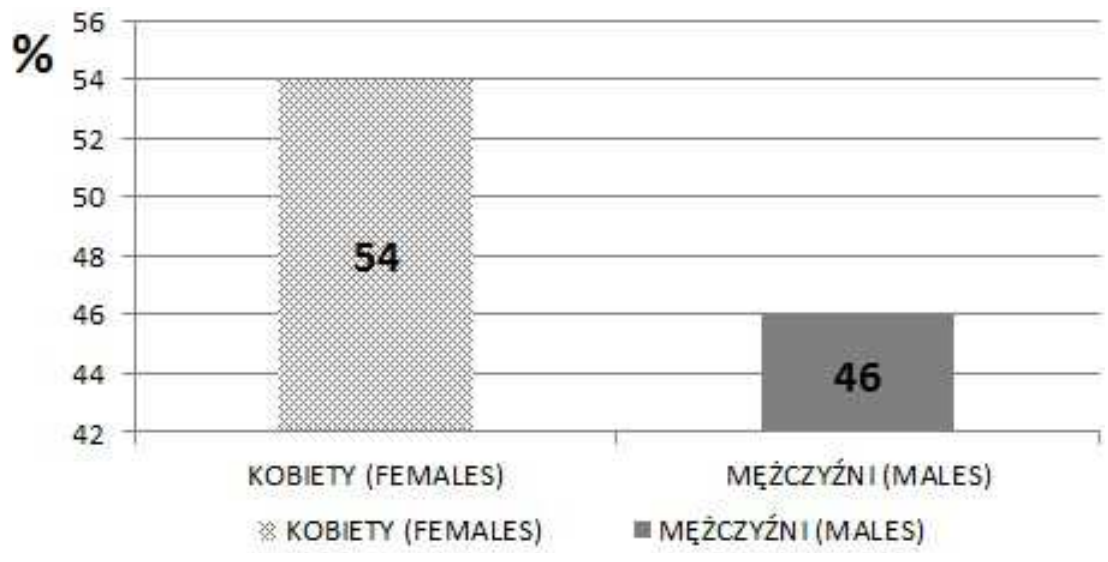

Ryc. 5. Procentowy rozkład płci w wykopie nr 69

Fig. 5. Percentage distribution by sex from trench No. 69

Następnie materiał poddano ocenie wieku. Na 14 czaszek w dwóch przypadkach zły stan zachowania uniemożliwił wykonanie analizy. Na rycinie 6 przedstawiono procentowy rozkład wieku na danym stanowisku: $33 \%$ osobników było w wieku adultus (20-35 lat), 58\% w wieku maturus (35-55 lat) i tylko 9\% w wieku senilis (powyżej 55. roku życia). 


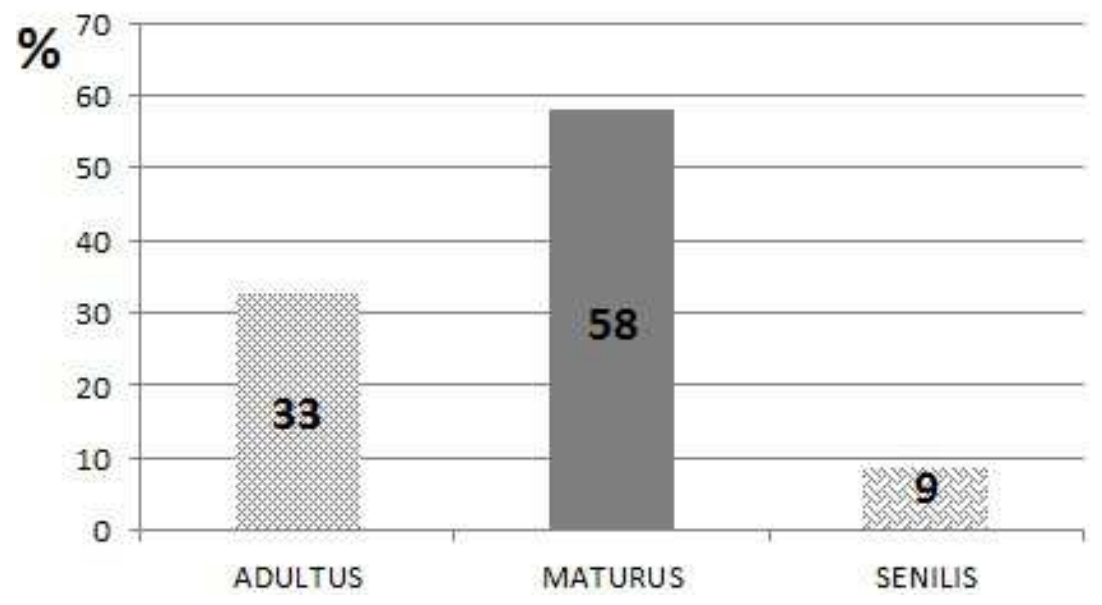

Ryc. 6. Procentowy rozkład wieku w wykopie $\mathrm{nr} 69$

Fig. 6. Percentage distribution by age from trench No. 69

$\mathrm{Na}$ rycinie 7 również przedstawiono rozkład wieku w badanej grupie, ale z uwzględnieniem podziału na płeć. W przypadku kobiet najbardziej liczną grupą jest kategoria adultus (60\%), a następnie maturus (40\%). Natomiast żadna z badanych kobiet w chwili śmierci nie była starsza niż 55 lat. Nieco inaczej sytuacja wygląda u mężczyzn. Dwie skrajne kategorie (adultus i senilis) są tak samo mało liczne. Zdecydowaną większość stanowili mężczyźni w środkowym przedziale wiekowym (aż 67\%).

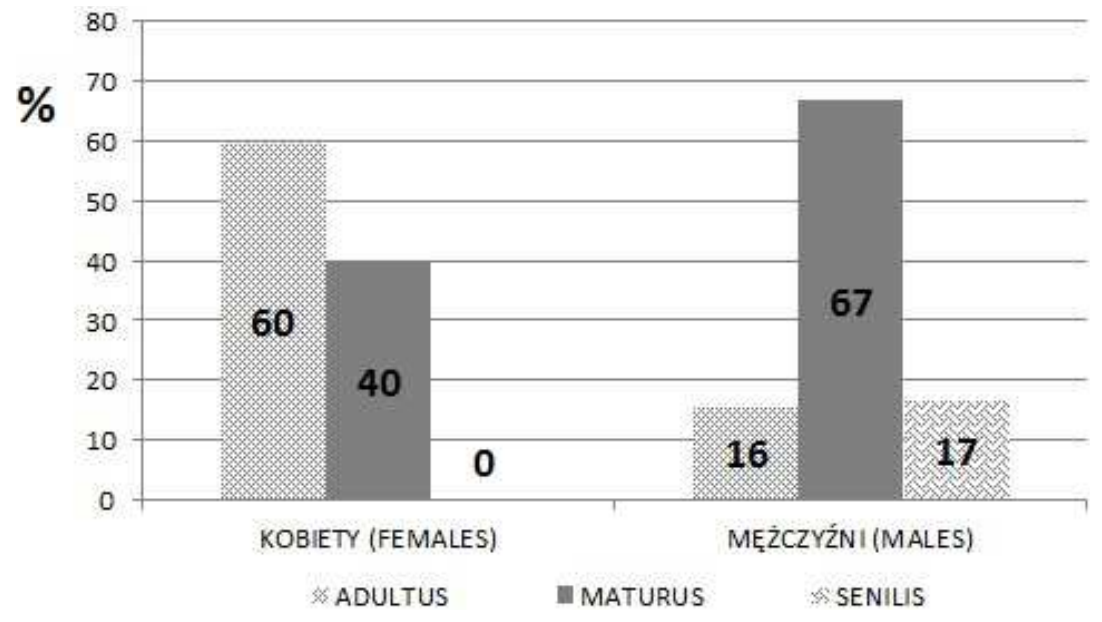

Ryc. 7. Procentowy rozkład wieku z podziałem na płeć w wykopie $\mathrm{nr} 69$

Fig. 7. Percentage distribution by age according to sex from trench No. 69 
Czaszki pochodzące z wykopu drugiego były w bardzo dobrym stanie. Do kategorii Calvarium i Calvaria zaklasyfikowano odpowiednio 36\% czaszek, a Calotta stanowiła tylko $28 \%$ badanej grupy.

\section{Analiza szczątków osobników dorosłych z wykopu nr 70}

Szkielety pochodzące z drugiego wykopu w zdecydowanej większości należały do osobników dorosłych. Na rycinie 8 pokazano, w jaki sposób kształtowały się ostateczne wartości dla szkieletu postkranialnego osobników z wykopu nr 70. Najbardziej liczebne okazały się kości długie kończyny dolnej i kość ramienna. Natomiast najrzadziej w materiale wystąpiły: mostek, łopatka, obojczyk oraz kość skokowa i kość piętowa. Spośród wszystkich elementów szkieletu postkranialnego kość udowa wystąpiła najczęściej. Na rycinie 9 pokazano, w jaki sposób kształtowały się wartości dla kości udowej z uwzględnieniem stron ciała.

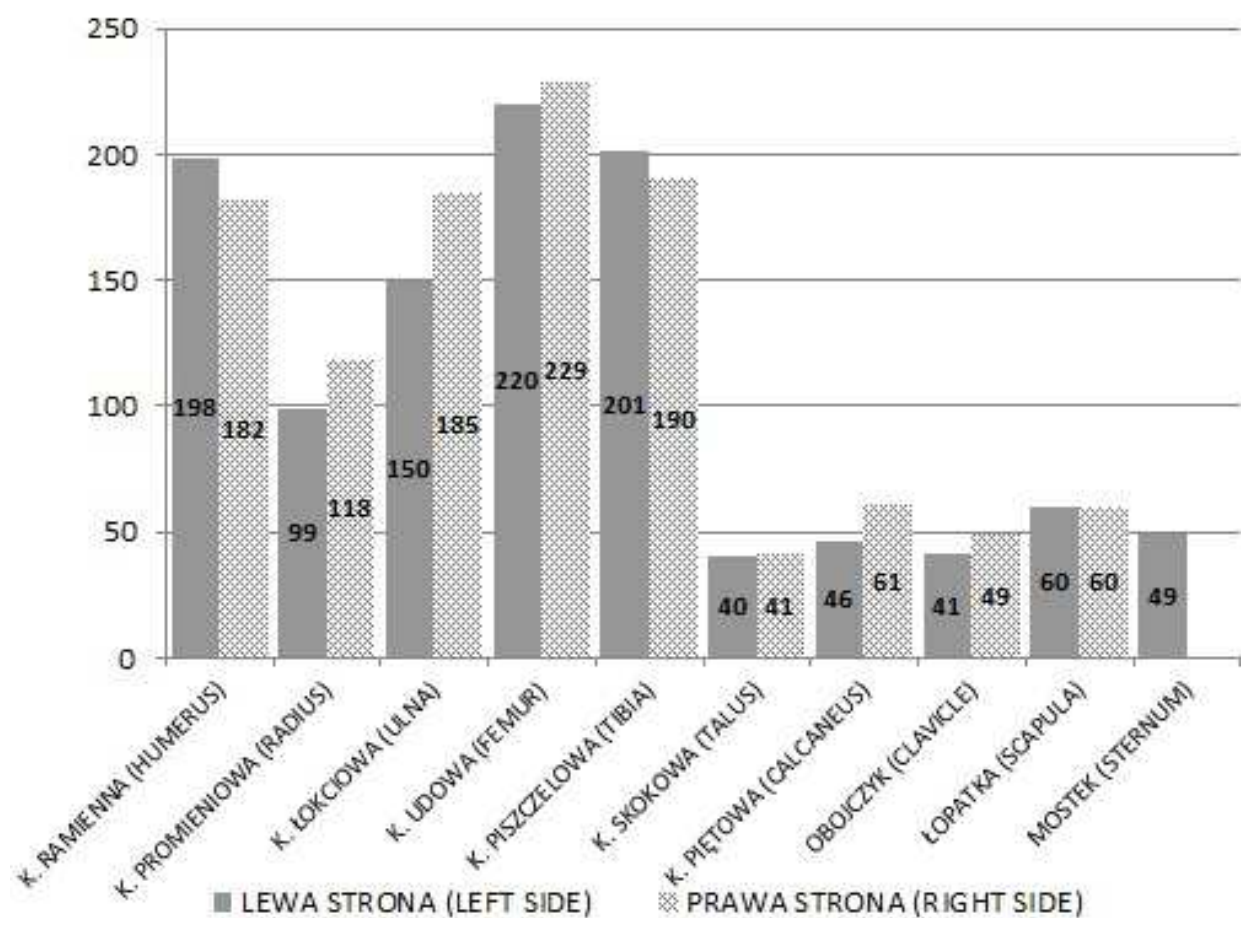

Ryc. 8. Ostateczne wartości dla szkieletu postkranialnego osobników dorosłych z wykopu $\mathrm{nr} 70$

Fig. 8. Final values of adult postcranial bones from trench No. 70 


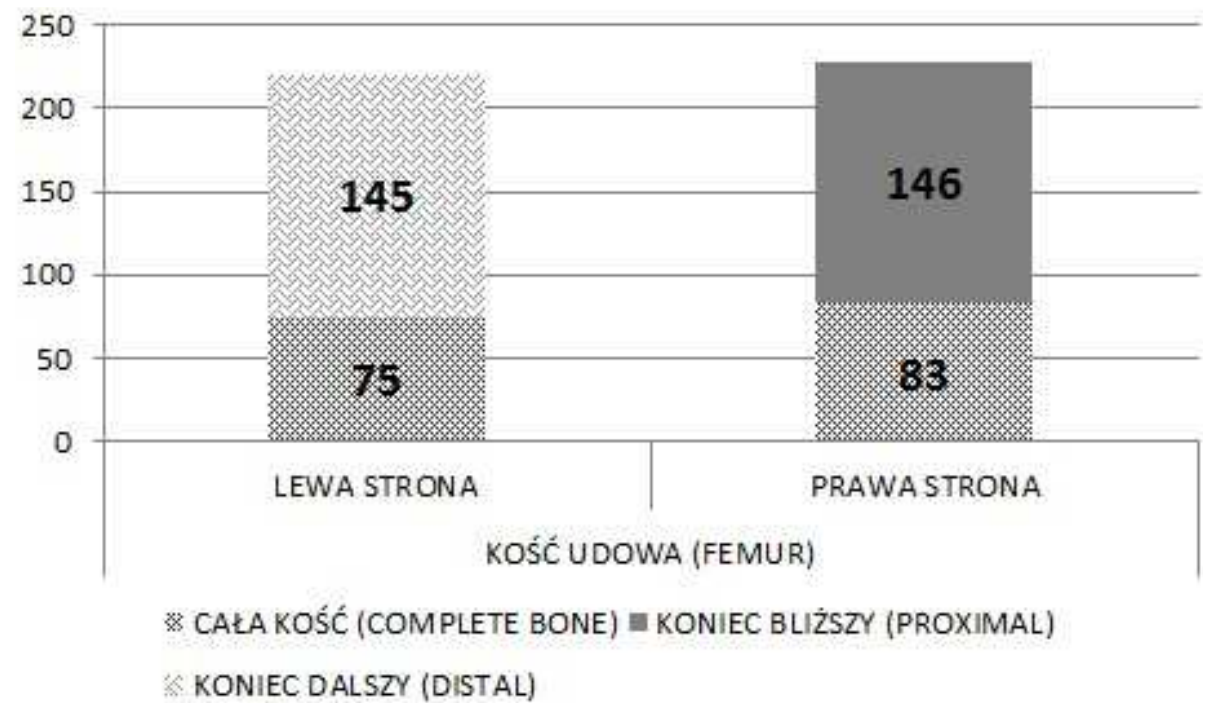

Ryc. 9. Ostateczna liczebność kości udowej po zsumowaniu kości całych i najliczniejszego końca w poszczególnej stronie ciała

Fig. 9. Final number of femur in total number of complete bones and the most numerous end in particular body side

Tabela 2. Liczebność elementów dla poszczególnych kości osobników dorosłych z wykopu nr 70 Table 2. Number of adult bones elements from trench No. 70

\begin{tabular}{|c|c|c|c|c|c|c|c|c|}
\hline \multirow{2}{*}{$\begin{array}{c}\text { Szkielet } \\
\text { postkranialny }\end{array}$} & \multicolumn{3}{|c|}{ Lewa strona ciała } & \multirow[b]{2}{*}{ Suma } & \multicolumn{3}{|c|}{ Prawa strona ciała } & \multirow[b]{2}{*}{ Suma } \\
\hline & $\begin{array}{c}\text { koniec } \\
\text { proksym. }\end{array}$ & $\begin{array}{c}\text { koniec } \\
\text { dystalny }\end{array}$ & $\begin{array}{l}\text { cała } \\
\text { kość }\end{array}$ & & $\begin{array}{c}\text { koniec } \\
\text { proksym. }\end{array}$ & $\begin{array}{c}\text { koniec } \\
\text { dystalny }\end{array}$ & $\begin{array}{l}\text { cała } \\
\text { kość }\end{array}$ & \\
\hline $\begin{array}{l}\text { Humerus } \\
\text { (k. ramienna) }\end{array}$ & 66 & 152 & 46 & 198 & 65 & 130 & 52 & 182 \\
\hline $\begin{array}{l}\text { Radius } \\
\text { (k. promieniowa) }\end{array}$ & 68 & 67 & 31 & 99 & 81 & 62 & 37 & 118 \\
\hline Ulna (k. łokciowa) & 117 & 33 & 33 & 150 & 147 & 24 & 38 & 185 \\
\hline Femur (k. udowa) & 139 & 145 & 75 & 220 & 146 & 132 & 83 & 229 \\
\hline $\begin{array}{l}\text { Tibia } \\
\text { (k. piszczelowa) }\end{array}$ & 104 & 130 & 71 & 201 & 116 & 111 & 74 & 190 \\
\hline $\begin{array}{l}\text { Talus } \\
\text { (k. skokowa) }\end{array}$ & & & 40 & 40 & & & 41 & 41 \\
\hline $\begin{array}{l}\text { Calcaneus } \\
\text { (k. piętowa) }\end{array}$ & & & 46 & 46 & & & 61 & 61 \\
\hline $\begin{array}{l}\begin{array}{l}\text { Clavicle } \\
\text { (obojczyk) }\end{array} \\
\end{array}$ & & & 41 & 41 & & & 49 & 49 \\
\hline Scapula (łopatka) & & & 60 & 60 & & & 60 & 60 \\
\hline $\begin{array}{l}\text { Sternum } \\
\text { (mostek) }\end{array}$ & & & & & 0 & & & \\
\hline
\end{tabular}


Biorąc pod uwagę wszystkie otrzymane liczebności z drugiego wykopu, można przyjąć, że na podstawie prawej kości udowej minimalna wielkość (MNI) pochowanej grupy osobników dorosłych to 229 osób.

W drugim etapie poddano ocenie 112 czaszek, z czego tylko w 79 przypadkach stan zachowania pozwolił na wykonanie oceny płci. Ostatecznie 23 czaszki zakwalifikowano jako kobiece, 53 jako męskie, a w przypadku 3 zestaw cech był na tyle niejednorodny, iż nie udało się jednoznacznie określić płci.

$\mathrm{Z}$ ryciny 10 wynika, iż zdecydowaną większość badanej grupy stanowili mężczyźni (aż 67\%). Otrzymane rezultaty można odnieść (lecz z dużą rozwagą) do wyników ilościowych, w których stwierdzono, że w danym ossarium pochowano nie mniej niż 229 osobników. Za ostrożnością w interpretowaniu powyższych wyników przemawia fakt, iż ocenie poddano wyłącznie czaszki (bez żuchwy); ze względu na na duży stopień wymieszania szczątków (brak możliwości dopasowania poszczególnych kości do osobnika) nie zastosowano kompleksowej metody oceny płci, która daje najlepsze rezultaty.

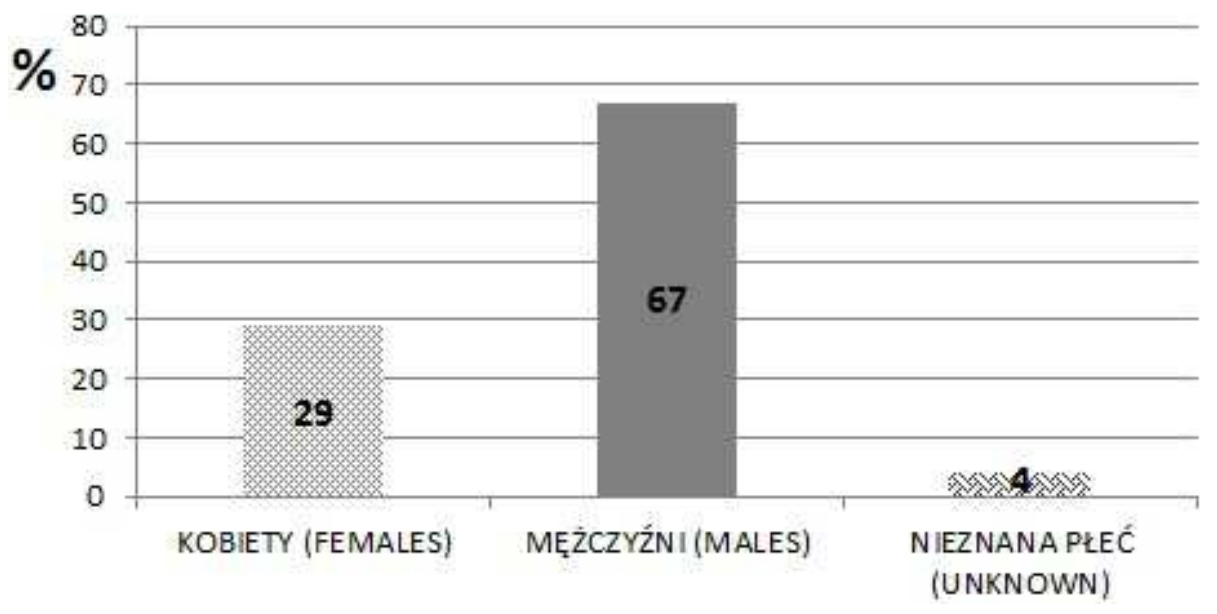

Ryc. 10. Procentowy rozkład płci na stanowisku nr 70

Fig. 10. Percentage distribution by sex from trench No. 70

Po analizie płci dokonano ponownej weryfikacji czaszek, tym razem w celu określenia wieku. Na 112 czaszek tylko w dwóch przypadkach stan zachowania uniemożliwił ocenę. Na rycinie 11 przedstawiono procentowy rozkład wieku na danym stanowisku. Wynika z niego, że 30\% osobników było w wieku adultus (20-35 lat), 49\% w wieku maturus (35-55 lat) i 21\% w wieku senilis (powyżej 55. roku życia). 


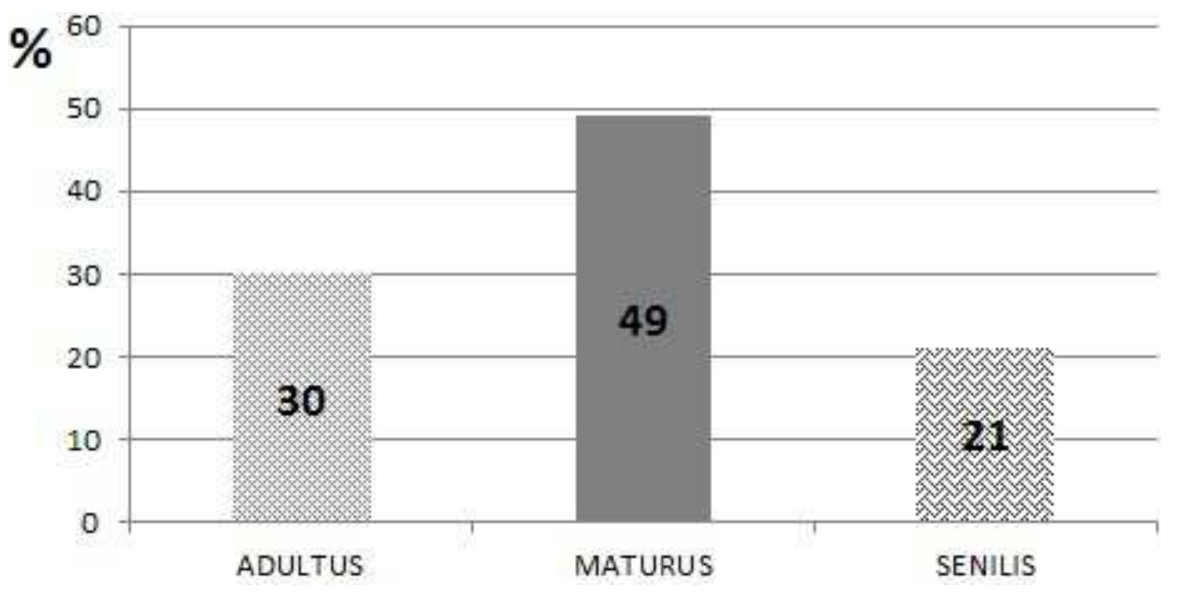

Ryc. 11. Procentowy rozkład wieku z wykopu nr 70

Fig. 11. Percentage distribution by age from trench No. 70

Rycina 12 również przedstawia rozkład wieku w badanej grupie, ale z uwzględnieniem podziału na płeć. W przypadku kobiet najbardziej liczną grupą jest kategoria maturus. Dwie pozostałe są reprezentowane w zdecydowanej mniejszości. Podobnie sytuacja wygląda u mężczyzn - z tym wyjątkiem, że różnica pomiędzy trzema kategoriami nie jest aż tak duża jak w przypadku pierwszym.

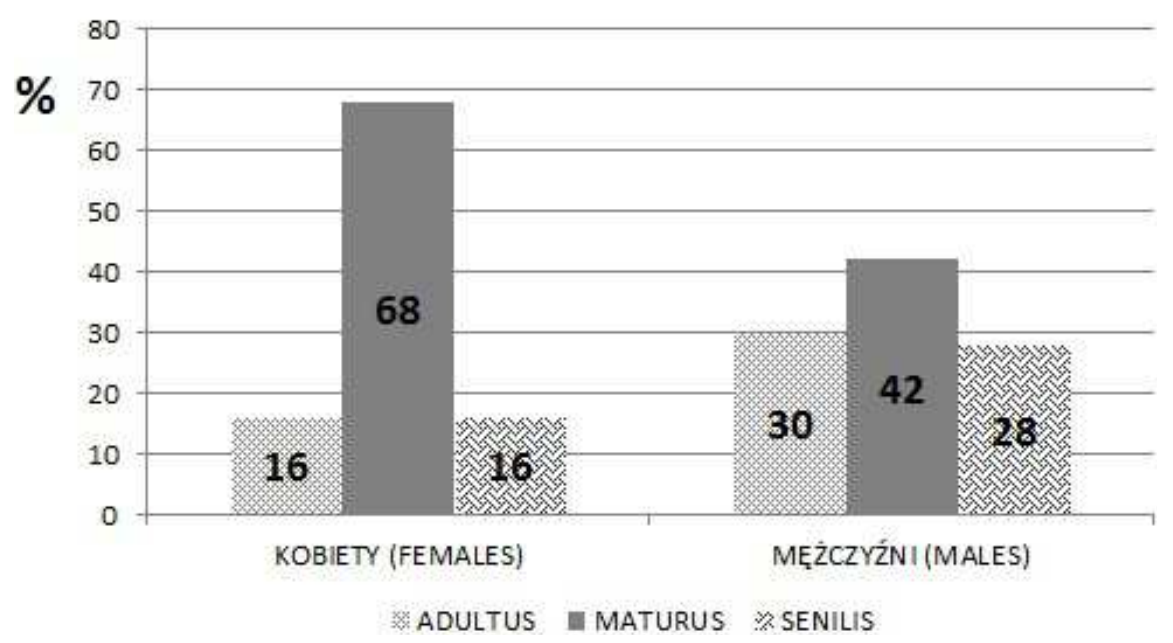

Ryc. 12. Procentowy rozkład wieku z podziałem na płeć z wykopu $\mathrm{nr} 70$ Fig. 12. Percentage distribution by age according to sex from trench No. 70 
Zdecydowana większość czaszek składała się tylko ze sklepienia. Taki stan zachowania bardzo ograniczał prawidłowe wykonanie analizy, zwłaszcza określanie płci, gdyż niemożliwa była ocena m.in.: wyrostka sutkowatego, wejścia oczodołu, łuku jarzmowego oraz powierzchni kości jarzmowej. Natomiast w określaniu wieku taki stan zachowania czaszek nie stanowił zbyt dużej przeszkody.

\section{Analiza szczątków dziecięcych z wykopu nr 69}

Ze względu na mniejsze wymiary krypty niż rozmiar ossuarium szczątki dziecięce nie były liczne. Na rycinie 13 przedstawiono ostateczne wartości dla szkieletu postkranialnego po zsumowaniu elementów całych i jednego z końców. Najliczniej reprezentowana była kość piszczelowa. W materiale wykopaliskowym nie odnotowano żadnego obojczyka, mostka oraz kości skokowej. W przypadku kości ramiennej i promieniowej zaobserwować można, iż jedna ze stron występowała częściej.

Spośród wszystkich elementów szkieletu postkranialnego kość piszczelowa występuje najliczniej (ryc. 13). Dodatkowo, tylko w jej przypadku zaobserwowano pojawienie się końca dystalnego (ryc. 14). Liczebność obu stron ciała była zbliżona, a większość próby stanowiły dość dobrze zachowane kości całe. Na podstawie prawej kości piszczelowej ustalono dolną granicę liczebności osobników dziecięcych: 6 osób. Zdecydowaną większość wydobytego materiału stanowiły kości całe.

Tabela 3. Liczebność elementów dla poszczególnych kości osobników w okresie dzieciństwa i młodzieńczym w wykopie $\mathrm{nr} 69$

Table 3. Number of immature bones elements from trench No. 69

\begin{tabular}{|c|c|c|c|c|c|c|c|c|}
\hline \multirow{2}{*}{$\begin{array}{c}\text { Szkielet } \\
\text { postkranialny }\end{array}$} & \multicolumn{3}{|c|}{ Lewa strona ciała } & \multirow[b]{2}{*}{ Suma } & \multicolumn{3}{|c|}{ Prawa strona ciała } & \multirow[b]{2}{*}{ Suma } \\
\hline & $\begin{array}{l}\text { koniec } \\
\text { proksym. }\end{array}$ & $\begin{array}{l}\text { koniec } \\
\text { dystalny }\end{array}$ & $\begin{array}{l}\text { cała } \\
\text { kość }\end{array}$ & & \begin{tabular}{|c|} 
koniec \\
proksym.
\end{tabular} & $\begin{array}{l}\text { koniec } \\
\text { dystalny }\end{array}$ & $\begin{array}{l}\text { cała } \\
\text { kość }\end{array}$ & \\
\hline $\begin{array}{l}\text { Humerus } \\
\text { (k. ramienna) }\end{array}$ & 0 & 0 & 1 & 1 & 1 & 0 & 3 & 4 \\
\hline $\begin{array}{l}\text { Radius } \\
\text { (k. promieniowa) }\end{array}$ & 1 & 0 & 3 & 4 & 0 & 0 & 2 & 2 \\
\hline Ulna (k. łokciowa) & 0 & 0 & 2 & 2 & 1 & 0 & 2 & 3 \\
\hline Femur (k. udowa) & 2 & 0 & 1 & 3 & 2 & 0 & 1 & 3 \\
\hline $\begin{array}{l}\text { Tibia } \\
\text { (k. piszczelowa) }\end{array}$ & 0 & 1 & 4 & 5 & 0 & 3 & 3 & 6 \\
\hline $\begin{array}{l}\text { Talus } \\
\text { (k. skokowa) }\end{array}$ & & & $\mathbf{0}$ & 0 & & & $\mathbf{0}$ & 0 \\
\hline $\begin{array}{l}\text { Calcaneus } \\
\text { (k. piętowa) }\end{array}$ & & & 1 & 1 & & & $\mathbf{0}$ & 0 \\
\hline $\begin{array}{l}\text { Clavicle } \\
\text { (obojczyk) }\end{array}$ & & & $\mathbf{0}$ & 0 & & & $\mathbf{0}$ & 0 \\
\hline Scapula (łopatka) & & & 1 & 1 & & & $\mathbf{0}$ & 0 \\
\hline $\begin{array}{l}\text { Sternum } \\
\text { (mostek) }\end{array}$ & & & & & 0 & & & \\
\hline
\end{tabular}




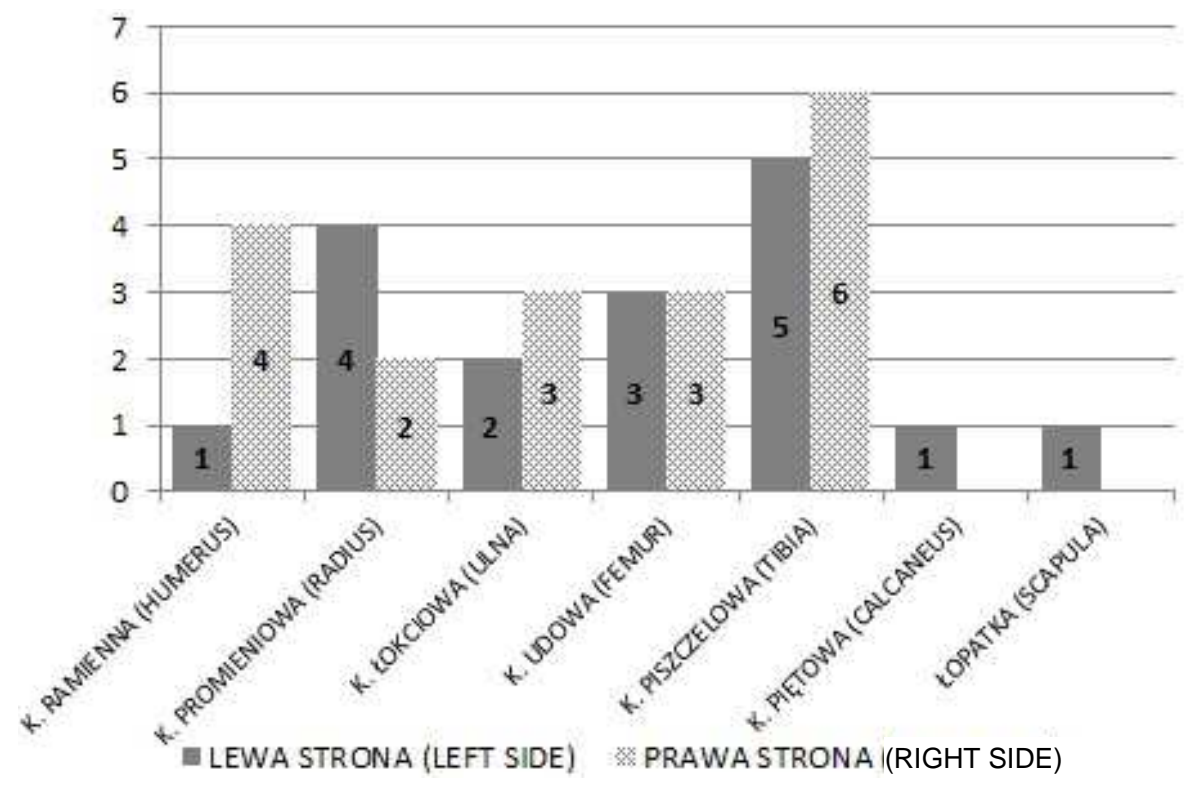

Ryc. 13. Ostateczne wartości dla szkieletu postkranialnego osobników w okresie dzieciństwa i młodzieńczym w wykopie $\mathrm{nr} 69$

Fig. 13. Final values of immature postcranial bones from trench No. 69

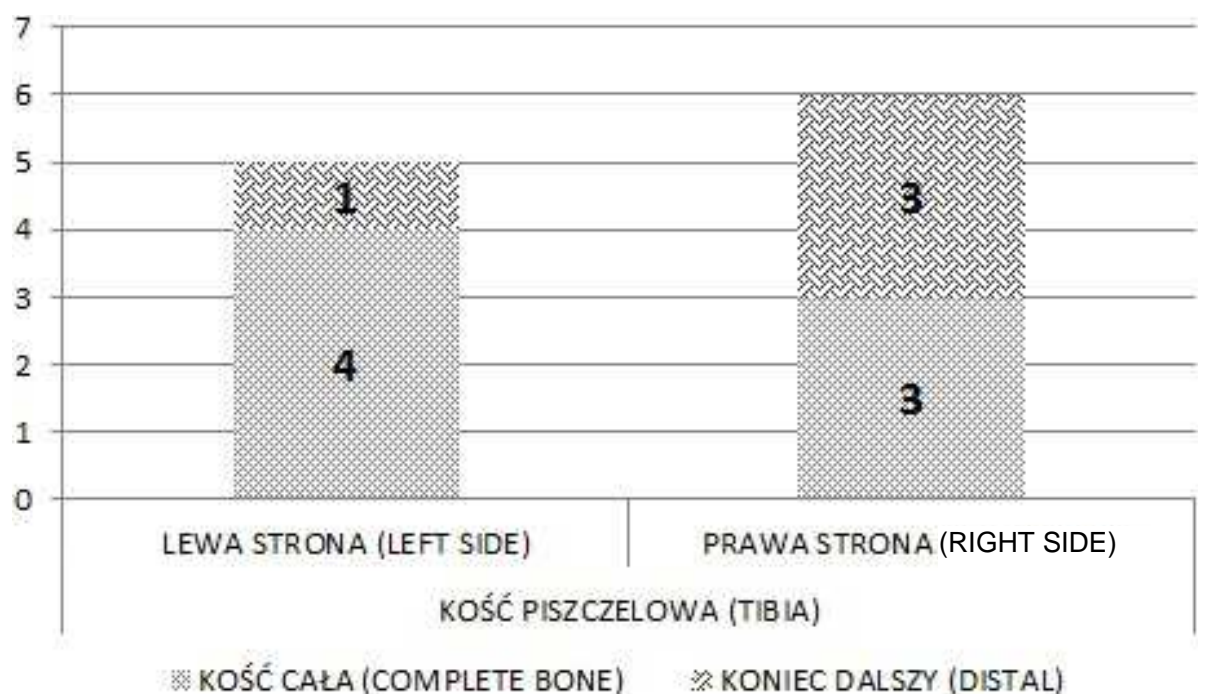

Ryc. 14. Ostateczna liczebność kości piszczelowej po zsumowaniu kości całych i najliczniejszego końca w poszczególnej stronie ciała

Fig. 14. Final number of tibia in total number of complete bones and the most numerous end in particular body side 


\section{Analiza szczątków dziecięcych z wykopu nr 70}

Liczebność szczątków dziecięcych pochodzących z pierwszego wykopu była bardzo mała. Wartości dla poszczególnych elementów przedstawiono w tabeli 4. Z tabeli wynika, że najliczniej reprezentowana jest kość udowa, natomiast dość słabo reprezentowane są kość promieniowa oraz kość łokciowa. W materiale wykopaliskowym nie odnotowano ani jednej kości piętowej, kości skokowej, obojczyka, łopatki czy mostka. Dodatkowo, w przypadku kości udowej, promieniowej oraz piszczelowej zaobserwować można, iż jedna ze stron występowała nieco częściej.

Tabela 4. Liczebność elementów dla poszczególnych kości osobników w okresie dzieciństwa i młodzieńczym z wykopu nr 70

Table 4. Number of immature bones elements from trench No. 70

\begin{tabular}{|l|c|c|c|c|c|c|c|c|}
\hline \multirow{2}{*}{$\begin{array}{c}\text { Szkielet } \\
\text { postkranialny }\end{array}$} & \multicolumn{4}{|c|}{$\begin{array}{c}\text { Lewa strona ciała } \\
\text { koniec }\end{array}$} & $\begin{array}{c}\text { koniec } \\
\text { proksym. }\end{array}$ & cała & Suma & \multicolumn{3}{c|}{ Prawa strona ciała } & \multirow{2}{*}{$\begin{array}{c}\text { koniec } \\
\text { proksym. }\end{array}$} & $\begin{array}{c}\text { koniec } \\
\text { dystalny }\end{array}$ & $\begin{array}{c}\text { cała } \\
\text { kość }\end{array}$ & Suma \\
\hline $\begin{array}{l}\text { Humerus } \\
\text { (k. ramienna) }\end{array}$ & 2 & $\mathbf{6}$ & $\mathbf{1}$ & 7 & 4 & $\mathbf{6}$ & $\mathbf{1}$ & 7 \\
\hline $\begin{array}{l}\text { Radius } \\
\text { (k. promieniowa) }\end{array}$ & $\mathbf{3}$ & 0 & $\mathbf{0}$ & 3 & 0 & $\mathbf{1}$ & $\mathbf{0}$ & 1 \\
\hline Ulna (k. lokciowa) & $\mathbf{3}$ & 0 & $\mathbf{0}$ & 3 & $\mathbf{3}$ & 0 & $\mathbf{0}$ & 3 \\
\hline Femur (k. udowa) & $\mathbf{1 4}$ & 11 & $\mathbf{3}$ & 17 & $\mathbf{1 3}$ & 12 & $\mathbf{0}$ & 13 \\
\hline $\begin{array}{l}\text { Tibia } \\
\text { (k. piszczelowa) }\end{array}$ & $\mathbf{3}$ & 2 & $\mathbf{1}$ & 4 & $\mathbf{7}$ & 1 & $\mathbf{0}$ & 7 \\
\hline $\begin{array}{l}\text { Talus } \\
\text { (k. skokowa) }\end{array}$ & & & $\mathbf{0}$ & 0 & & & $\mathbf{0}$ & 0 \\
\hline $\begin{array}{l}\text { Calcaneus } \\
\text { (k. piętowa) }\end{array}$ & & & $\mathbf{0}$ & 0 & & & $\mathbf{0}$ & 0 \\
\hline $\begin{array}{l}\text { Clavicle } \\
\text { (obojczyk) }\end{array}$ & & & $\mathbf{0}$ & 0 & & & $\mathbf{0}$ & 0 \\
\hline Scapula (łopatka) & & & $\mathbf{0}$ & 0 & & & $\mathbf{0}$ & 0 \\
\hline $\begin{array}{l}\text { Sternum } \\
\text { (mostek) }\end{array}$ & & & & & & & & \\
\hline
\end{tabular}

Kość udowa jest najbardziej liczna spośród pozostałych elementów szkieletu (ryc. 15) i podobnie jak w przypadku poprzednich analiz - stan zachowania obu ich końców jest do siebie zbliżony. Dzięki otrzymanym wartościom dla lewej kości udowej (ryc. 16) można stwierdzić, że minimalna liczba pochowanych dzieci na danym stanowisku to 17 osób. 


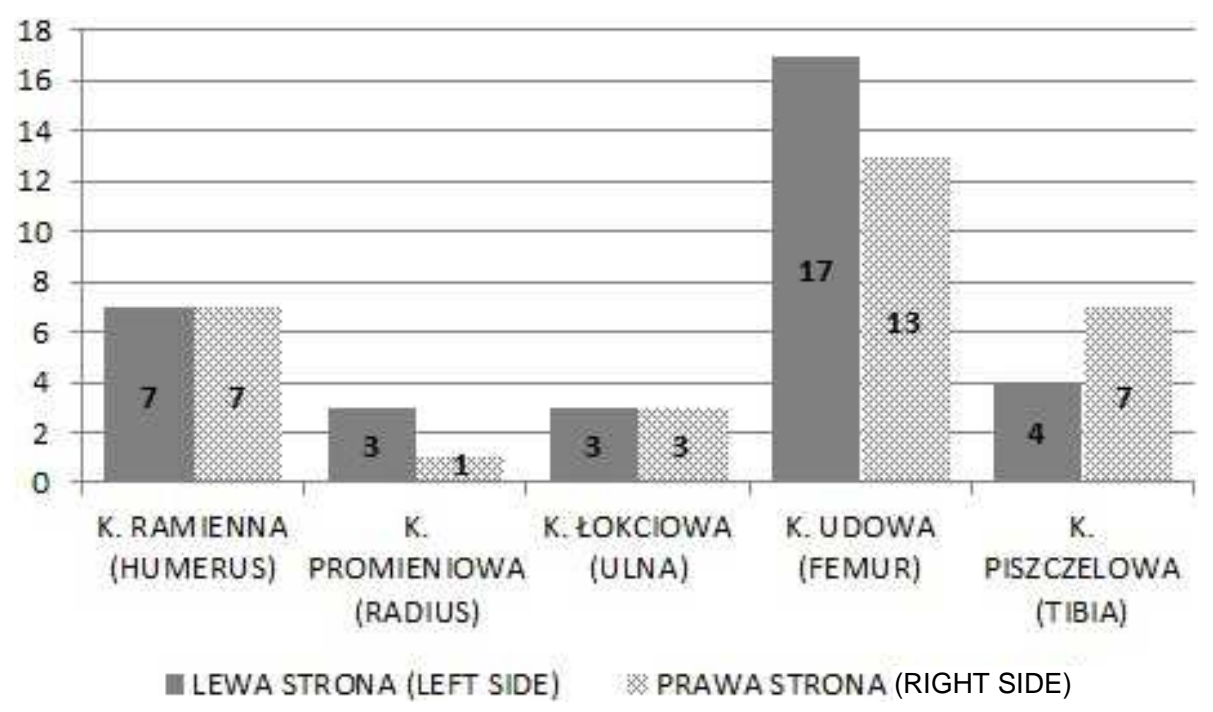

Ryc. 15. Ostateczne wartości dla szkieletu postkranialnego osobników w okresie dzieciństwa i młodzieńczym z wykopu nr 70

Fig. 15. Final values of immature postcranial bones from trench No. 70

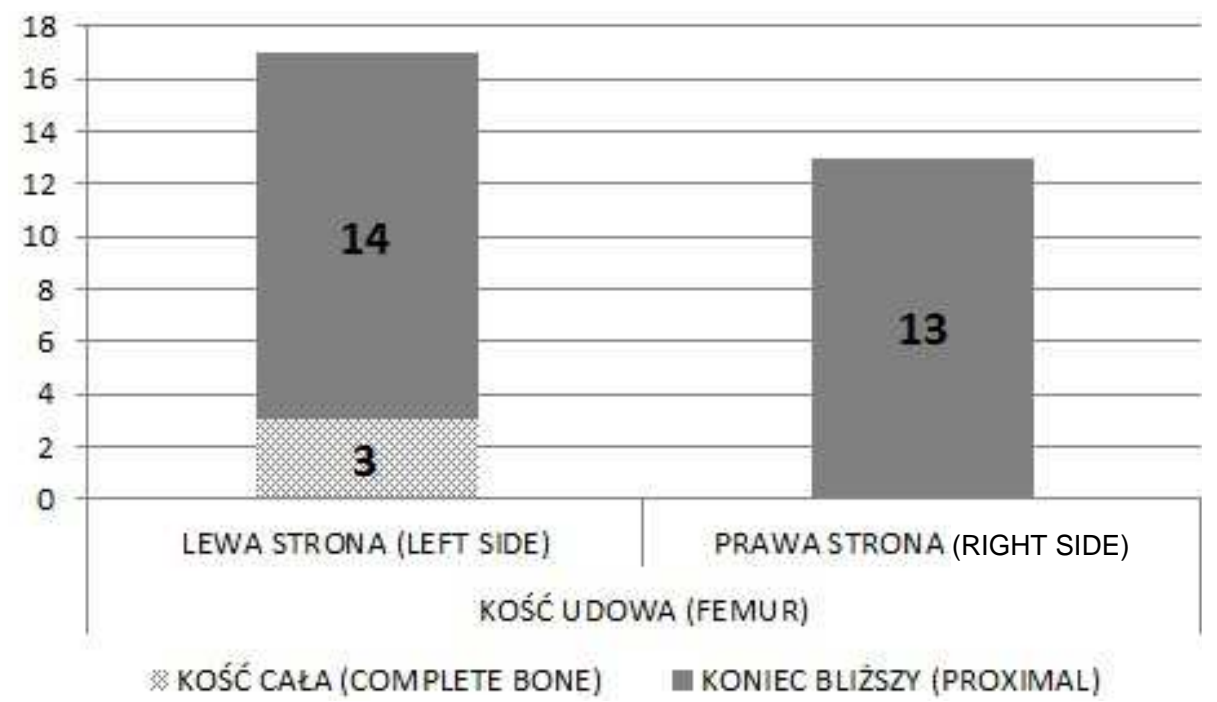

Ryc. 16. Ostateczna liczebność kości udowej po zsumowaniu kości całych i najliczniejszego końca w poszczególnej stronie ciała

Fig. 16. Final number of femur in total number of complete bones and the most numerous end in particular body side 


\section{DYSKUSJA}

Eksplorowane kości z wykopu i krypty, znajdujących się w kościele Najświętszej Marii Panny, prawdopodobnie zostały przeniesione z Bazyliki Archikatedralnej Świętych Apostołów Piotra i Pawła. Ich powtórne złożenie może tłumaczyć tak dużą fragmentację i przemieszanie materiału kostnego. Na podstawie przyjętej metodyki obliczono, iż w wykopie nr 69 pochowano nie mniej niż 17 osób dorosłych i 6 dzieci. Z kolei w wykopie nr 70 znajdowało się nie mniej niż 229 osób dorosłych i 17 dzieci.

Najlepszym wskaźnikiem ilościowym dla osobników dorosłych pod względem zachowanych obu końców, jak i całej kości, okazały się kość udowa oraz kość piszczelowa. Wynika to z ich dużej masywności (są bardziej odporne na złamania) oraz charakterystycznej budowy anatomicznej (nie ma trudności w rozpoznaniu nawet małych elementów). Najmniej liczne były kość piętowa, kość skokowa, mostek, obojczyk oraz łopatka. Zaobserwowano także gorszy stan zachowania materiału kostnego z wykopu nr 70, gdzie do kategorii Calotta zaklasyfikowano 56\% czaszek, natomiast w wykopie nr 69 kategoria Calotta stanowiła tylko 28\%. Różnica ta prawdopodobnie została spowodowana innymi warunkami deponowania. W przypadku wykopu nr 70 kości były zrzucane do głębokiego dołu, a następnie przysypane ziemią i gruzem. W krypcie natomiast złożono zdecydowanie mniejszą ilość szkieletów, którą przykryto cienką warstwą gruzu.

Ocenie wieku i płci poddano kolejno 14 i 13 czaszek z wykopu nr 69 oraz 110 i 79 czaszek z wykopu nr 70. Analizowany materiał z dwóch miejsc nie był jednakowy pod względem płci. W krypcie odnotowano podobną liczbę kobiet i mężczyzn (54\% i 46\%), z kolei w wykopie nr 70 stwierdzono przewagę mężczyzn (29\% i 67\%), a w przypadku 3 osobników (4\%) zestaw cech nie pozwolił na jednoznaczną ocenę.

Rozkład wiekowy mężczyzn z wykopu nr 69 i nr 70 nie różnił się znacząco. W obu przypadkach najliczniejszą kategorią był maturus (67\% i 42\%), następnie adultus (16\% i 30\%) i senilis (28\% i $28 \%$ ). Wśród kobiet wystąpiło większe zróżnicowanie. W krypcie największą ilość odnotowano wśród kategorii adultus (60\%), następnie dla maturus (40\%), z kolei nie stwierdzono żadnego osobnika po 55. roku życia. Rozkład wiekowy kobiet z wykopu nr 70 był następujący: 16\% adultus, 68\% maturus i $16 \%$ senilis. Należy wziąć pod uwagę, iż wyciąganie wniosków na podstawie tak mało liczebnej pierwszej grupy powinno być traktowane z dużą powściągliwością.

Podobnie jak w przypadku osobników dorosłych, najlepszym wskaźnikiem ilościowym dla szczątków dziecięcych były kość udowa i kość piszczelowa. Najmniej liczebne okazały się kość skokowa oraz obojczyk. Stan zachowania materiału był zdecydowanie lepszy w krypcie, w której odnotowano dużą liczbę całych kości. Przyczyną większego rozdrobnienia w wykopie nr 70 (oprócz zrzucenia ich do głębokiego dołu) mogły być liczne masywne kości osobników dorosłych.

Dzięki otrzymanym liczebnościom poszczególnych kości możliwe jest w przyszłości wyeliminowanie elementów najmniej licznych i skupienie się wyłącznie na 
tych, które są najlepszymi wskaźnikami ilościowymi. Takie podejście selekcyjne sprawiłoby, że metoda stałaby się szybsza i łatwiejsza do zastosowania.

Największą wadą takiego podejścia badawczego jest niemożność stwierdzenia maksymalnej wielkości grupy. Co prawda, jej uzyskanie byłoby możliwe poprzez dodanie do siebie wartości wszystkich elementów kości (najliczniejszej), ale otrzymana liczba byłaby za duża, a zatem uznana za mało wiarygodną.

\section{PODZIĘKOWANIA}

Pragnę serdecznie podziękować Pani prof. Hannie Kóčce-Krenz za umożliwienie przeprowadzenia badań, Pani Oldze Antowskiej-Gorączniak i Panu Andrzejowi Sikorskiemu za udostępnienie materiałów fotograficznych oraz wszystkim osobom, które pomagały mi w trakcie wykopalisk archeologicznych.

\section{BIBLIOGRAFIA}

Ascádi G., Nemeskeri I.

$1970 \quad$ History of Human Life Span and Mortality, Budapest.

Bradley J.A.

2008 Recovery, Analysis, and Identification of Commingled Human Remains, New York. Brothwell D.R .

1981 Digging up Bones, London.

Hunter J., Cox M.

2005 Forensic Archaeology: Advances in Theory and Practice, New York.

Pickering R., Bachman D.

2009 The use of Forensic Anthropology, Boca Raton.

Piontek J.

1996 Biologia populacji pradziejowych, Poznań.

Thomas P.

2003 Forensic Anthropology. The Growing Science of Talking Bones, New York.

\section{ANTHROPOLOGICAL EXAMINATION OF OSTEOLOGICAL MATERIAL FROM TRENCHES NUMBER 69 AND 70 AT POZNAŃ-OSTRÓW TUMSKI 9/10}

\section{S u m m a r y}

Mass graves and ossuaries analysis requires the cooperation of specialists in anthropology and archaeology. The results of these studies have a huge cognitive value - for the improvement of methodology and a practical value - useful in archaeological interpretation. Numerous methodological studies devote attention to the research of the disaster or war victims. Due to the complete- 
ly different nature of the discovered human remains in the St. Mary's Church on the Ostrów Tumski in Poznań, a new testing procedure has been created.

The research material came from two trenches, the bones were highly fragmented and mixed up. The trench No. 69/2011 was a modern crypt with brick stairs (dimensions $2.80(3.0) \times 1.6 \mathrm{~m}$.). The second trench No. 70/2011 was deep and completely filled with bone remains mixed with soil and rubble. Based on small grave goods (clothes and footwear elements, pins, rivets), it was determined that the material was from the early medieval period.

The purpose of this study was to estimate the minimum number of individuals (MNI) and determine sex and age structure of the people found in the trench. At first I focused on the postcranial skeleton. For each of a bone (including the divide to body sides) the following elements were counted: a proximal end, a distal end, the shaft and the whole bone. For the whole bone and one of the most numerous ends the amounts were added up. According to the received data it was possible to estimate the MNI. The final calculation did not take into account the shafts of the bones, because of their fragmentation. Due to the excessive amount of the remaining bones fragments, only the following bones were counted: humerus, radius, ulna, femur, tibia, calcaneus, talus, sternum, scapula and clavicle. The second phase of work was carried out on a group of remains in which age of the people was more than 20 years. Sex assessment was conducted on a base of G. Acsadi i J. Nemeskeri (1970) method. Whereas the age at death was determined using the degree of cranial suture obliteration (Martin 1928). The material was classified into following categories: adultus (20-35 years), maturus (35-55 years) and senilis (more than 55 years). Children's bones was tested only in the first phase. The second phase was omitted because of not enough amount of the material.

Based on the methodology it has been calculated that in the trench No. 69 were buried no less than 17 adults and 6 children. On the other hand, the minimum number of people in the trench No. 70 was set at 229 adults and 17 children. The best quantitative indicator turned out to be femur and tibia. This is due to their great massiveness (they are more resistant to fracture) and characteristic anatomy structure (no difficulties in identifying even small parts). The worse condition of the bones in the trench No. 70 was probably caused by others deposit conditions. In the case of the trench No. 70 bones were thrown into a deep pit and covered with soil and rubble. While fewer skeletons were placed in the crypt and were covered with a thin stratum of rubble.

The analyzed material from the two locations was not identical in terms of the sex structure. Similar number of men and women $(54 \%$ and $46 \%$ ) was found in the crypt while more men (29\% and $67 \%$ ) were in the trench No. 70 and in the case of three individuals (4\%) set of features did not allow for a clear sex assessment. Age distribution of men from the trench No. 69 and No. 70 didn't differ significantly, in both cases the largest category was maturus (67\% and 42\%). Among women there was a greater diversity. In the crypt the most numerous category was adultus $(60 \%)$, while maturus $(68 \%)$ was the largest group in the second trench No. 70.

Due to the received quantities of each bone it will be possible, to eliminate the least numerous elements and focus only on those that are the best quantitative indicators. Such an approach would make the selection and method faster and easier to use. The biggest disadvantage of this method is that the maximum size of the group may not be obtained. Although it would be possible to obtain the number by adding up the values of all elements of most numerous bone but the received number would be highly unlikely. 